\title{
A partnership brings improved access to folklore scholarship
}

\author{
By Daniel Uchitelle
}

Director, Center for Information Services

Modern Language Association

\section{Indiana University's Library and Folklore Institute form a Cooperative Folklore Bibliography Project with the Modern} Language Association.

$\mathbf{T}$ he Modern Language Association and Indiana University have embarked on an unusual program designed to increase the indexing coverage of a subject area-folklore-covered in the MLA International Bibliography, one of the major reference works in the humanities. The project is designed to involve IU folklore graduate students and faculty as subject specialist volunteer indexers, and to enlist the support of Indiana University as an institutional sponsor for one section of the MLA Bibliography. In addition to enhancing the coverage of folklore scholarship, it is hoped that this project will serve as a model for cooperation between library collections and publishers in other scholarly fields.

The MLA Bibliography analyzes monographs, monographic series, festschriften, dissertations, and periodicals, with citations for periodical articles making up the greater part of each annual compilation. Currently, over 2,500 journal titles are examined. Entries are contributed from two sources: a small team of in-house indexers working full time at MLA headquarters in New York, and a network of approximately 200 volunteers, known as field bibliographers, working at academic institutions throughout the world. The field bibliographer system allows the MLA to draw on the subject expertise of the same scholars who will be the ultimate users of the bibliography, and permits the bibliography to closely track and reflect the latest developments in the world of humanities research.

There are some serious problems with this system. In addition to the difficulties of maintaining communications with and coordinating such a large group of contributors, there is the more serious problem of access to material for coverage. The MLA has virtually no acquisitions budget, and relies on appeals to journals for complimentary subscriptions in order to supply its in-house indexers with material. What cannot be obtained or covered at MLA headquarters must be handled by field bibliographers-volunteers who, in consultation with MLA staff editors, are responsible for choosing titles for consistent coverage. Despite this responsibility, most field bibliographers have little direct control over the material being received and processed by their institution's libraries. In decisions to add or drop titles from the collection, or to 
expedite or delay processing, consideration is rarely given to the presence at the institution of one or two field bibliographers for MLA. Moreover, field bibliographers work as individuals, often moving from one university to another, and it is difficult to maintain continuity of coverage when moving between collections. For this reason, the MLA Bibliography, despite its many strengths, has been plagued by inconsistent coverage of all but the most widely held journal titles.

An additional problem for field bibliographers is the lack of encouragement within their institutions, for while everybody supports in general the principles of service to the field and the importance of bibliographic analysis to research, few academic departments have given substantive support to their own faculty and graduate students working as field bibliographers.

This twin burden of lack of consistent access to titles and lack of administrative encouragement has been a chronic problem and has prevented the MLA International Bibliography from achieving its full potential in breadth of coverage. Recently, the MLA began looking into ways to strengthen the field bibliographer system while establishing more complete subject coverage within the bibliography. After examining a number of potential approaches to this problem, it was decided to initiate a project that would address the major deficiencies of the field bibliographer system by creating an institutional locus for bibliographers working within specific subject areas. An institutional affiliation covering a single topical area could be designed and situated to draw on the best library collections and the strongest academic departments in each of the areas covered by the bibliography.

The initial outlines of this project were first discussed at the MLA in 1988. Discussion centered on two potential subject areas: East European literature and folklore. Both of these subjects are covered in depth in the annual bibliography, but it was felt that much material was still being missed.

In the fall of 1988 the topic was raised for discussion at the annual American Folklore Society convention. Since 1971, the AFS has supported the publication of the folklore section of the annual bibliography with a cash subvention. More recently, a number of folklorists had independently been mulling over the possibility of strengthening the link between their discipline and the MLA. The proposal of a cooperative bibliography project generated great enthusiasm at the AFS convention, and convention participants made many valuable suggestions.

On the subject of an institutional sponsor, there was almost complete consensus that the best site, in terms of both collection strength and potential administrative support, would be Indiana University in Bloomington, home of the IU Folklore
Institute and North America's largest folklore library collection.

Thus began a series of planning meetings between AFS members, IU administrators and librarians, and the staff of the MLA. The result of these meetings was a draft of the cooperative project, sponsored by the IU Folklore Institute, the IU Library, and the MLA. The project was designed to recruit field bibliographers from the Institute and give them direct access to materials in the folklore collection of the library. Administrative coordination at IU would be provided by Polly Grimshaw, folklore librarian, in consultation with Inta Gale Carpenter, associate director of special projects in the Folklore Institute. Local coordination by Grimshaw and Carpenter would assure that the project receives maximum budgetary and administrative support both in the library and in the Folklore Institute. Training, final editing, authority control, production of the bibliography, and overall coordination of the project would be carried out by the MLA staff, who are also responsible for disseminating the finished product.

After months of additional discussion and planning, the project was officially launched in September 1989. The MLA assigned staff time and expenses for recruiting and training IU participants; the IU Folklore Institute committed funds for the 1989-1990 academic year to hire a project coordinator; and the IU library provided supervision and workspace in the folklore collection office.

Moira Smith, the project coordinator hired by the Folklore Institute, began recruiting volunteer field bibliographers in January 1990. The Folklore Institute publicized the project in seminars and through its newsletter, and actively encouraged both graduate students and faculty to sign on for training. Titles for coverage were chosen by volunteers based on their interests and their language proficiencies. Polly Grimshaw, the folklore librarian, arranged to have all newly arrived issues of relevant journals available to IU field bibliographers. Equally important, she was able to use the library's serials acquisitions records to inform the MLA about discontinued, renamed, new, and delayed publications in folklore.

The Cooperative Bibliography Project has been in place for a year, and it is both popular and successful. The number of folklore citations in the current MLA International Bibliography is almost $30 \%$ above the previous year's total, and we plan to continue to expand and refine the project. One refinement will involve the creation of a graduate course in folklore research methodologies which will include training as an MLA field bibliographer. To expand the project, an attempt will be made to recruit Folklore Institute alumni as volunteers to cover those titles which are not available in Bloomington. 
We hope that in the future this project can be duplicated at other institutions with other subjects in the bibliography. In the meantime, we hope that this project will demonstrate the benefits of cooperation between academic departments, libraries, and the publishers of bibliographic reference works, and will help to train an ever expanding group of scholars in the art of indexing and bibliography.
Author's note: The development of this project is the result of the efforts of many individuals. In particular, the author wishes to acknowledge the assistance of Richard Bauman, Inta Carpenter, Polly Grimshaw, Moira Smith, and Catharine Wall. For a history of the place of folklore in the bibliography, see Michael Taft, "The Folklore Section of the MLA International Bibliography," International Folklore Review 2 (1982): 61-64.

\section{Subject experts needed for MLA Bibliography project}

The Modern Language Association has requested assistance from ACRL and the RASD Reference Tools Advisory Committee on a study of the scope and overlap in the MLA Bibliography and other reference works. The project will be explained at the Midwinter meeting (Saturday, January 12, 9:30-11:00 a.m.) and interested participants are invited to attend. ACRL president, Barbara J. Ford, has appointed Elaine Franco, University of California, Davis, and Eva Sartori, University of Nebraska, Lincoln, to co-chair the project.

According to Daniel Uchitelle, interested participants should have a broad knowledge of published reference works and the ability to analytically compare scope, depth, and completeness between one work and another. It is anticipated that between 10 and 20 members will be needed to complete the project by November 1, 1991 .

Participants will choose a classified category in which they have expertise from the Bibliography. They will undertake a detailed examination of the extent and nature of coverage of that area in the bibliography versus other currently from the Bibliography from the Bibliography available reference works. In addition, some areas not currently covered by the bibliography, such as Middle Eastern literature, will be examined. Once the examination is completed, participants will write a report for each classified section describing their findings. Uchitelle states that, "These reports will then be discussed by the committee as a whole, and a comprehensive set of recommendations will be formulated to help guide the MLA in focusing its indexing resources most effectively."

For more information, contact the committee co-chairs: Elaine Franco, Cataloging Department, Shields Library, University of California, Davis, CA 95616-5292, (916) 752-9860; Eva Sartori, Central Reference Services, 203B Love Library, University of Nebraska-Lincoln, Lincoln, NE 68588-0410, (402) 472-6987.

\section{ACRL considers future of Sixth National Conference in Phoenix}

The ACRL Executive Committee met on November 9-10, 1990, and discussed the future of the April 1-4, 1992, ACRL National Conference. The committee was concerned that Arizona voters had rejected a paid holiday honoring the Rev. Martin Luther King Jr. National reaction to the narrowly defeated referendum has been strong and some groups are considering boycotting the state.

Donald E. Riggs, dean of university libraries at Arizona State University and a member of the ACRL National Conference Executive Committee, reported that Arizona Governor Rose Mofford could issue an executive order to create a paid state holiday honoring King. He also stated that the city of Phoenix continues to have a King holiday.

At the 1990 ALA Annual Conference, the ACRL National Conference Committee, chaired by Jo- seph A. Boissé, University of California, Santa Barbara, discussed what ACRL might do if the King holiday was rejected by the voters. The committee recommended to the ACRL Board that ACRL keep its commitment to meet in Phoenix and make cultural diversity a major theme of the conference. Program co-chairs, Clarence Chisholm, Pennsylvania State University, and Sherrie Bergman, Wheaton College, are contacting major black leaders to speak at the conference.

ACRL President Barbara J. Ford reported that the ACRL Board would keep a close eye on developments in Arizona. She stated that she would confer with Arizona librarians during the November meeting of the Arizona State Library Association. Ford is speaking at the conference. 